\title{
Are the vegetation structure and composition of the shrubby Caatinga free from edge influence?
}

\author{
André Maurício de Melo Santos ${ }^{1}$ and Bráulio Almeida Santos 2,3
}

Received: Juny 13, 2007. Accepted: March 11, 2008

\begin{abstract}
RESUMO - (A estrutura e a composição da vegetação da Caatinga arbustiva são livres da influência de borda?). A influência de borda, ou efeito de borda, leva a diversas alterações biológicas em paisagens fragmentadas. Embora muito estudada em ecossistemas florestais, a influência de borda permanece desconhecida para a Caatinga. Baseada nas condições físicas e biológicas da Caatinga arbustiva, nossa predição a priori foi que este tipo de vegetação não sofre influência de borda em termos de estrutura e composição de espécies. Nós amostramos arbustos, cactos e árvores em 20 parcelas de $200 \mathrm{~m}^{2} \mathrm{em}$ bordas antigas (> 60 anos de idade) e interiores de um fragmento de 690 ha, parcialmente isolado e circundado por Opuntia ficus-indica. Altura das plantas, diâmetro ao nível solo, densidade de indivíduos e riqueza e diversidade de espécies foram estatisticamente iguais entre os habitats de borda e interior. A magnitude da influência de borda variou de -0,027 a 0,027, indicando baixa importância ecológica da criação de bordas para as variáveis analisadas. Adicionalmente, a similaridade florística entre os habitats alcançou $90 \%$ e uma análise de componentes principais mostrou que a composição de espécies varia de forma similar na borda e no interior. O conjunto dos resultados indica que a vegetação do fragmento estudado não é ecologicamente afetada pela criação de bordas e sugere que alterações nas condições físicas e na disponibilidade de recursos após a criação das bordas são insuficientes para eliminar plantas já estabelecidas ou alterar o recrutamento e a sobrevivência de novos indivíduos.
\end{abstract}

Palavras-chave: arbustos, efeito de borda, fragmentação de habitats, vegetação arbustiva sazonal

\begin{abstract}
Are the vegetation structure and composition of the shrubby Caatinga free from edge influence?). Edge influence, or edge effect, drives many biological changes in fragmented landscapes. This has been extensively studied in many forest ecosystems, but it remains to be described for the Brazilian Caatinga. Based on the biotic and physical conditions of the shrubby Caatinga, our prediction a priori was that this type of vegetation is free from edge influence in terms of vegetation structure and composition. We sampled shrubs, cacti and trees in twenty $200 \mathrm{~m}^{2}$ plots on old edges ( $>60 \mathrm{yrs}$ old) and interior of a 690 ha fragment, partially isolated and surrounded by Opuntia ficus-indica cacti. Plant height, stem diameter at ground level, stem density, species richness and diversity were statistically equal between edge and interior habitats. Magnitude of edge influence varied from -0.027 to 0.027 , indicating low ecological importance of edge creation for the measured variables. Additionally, floristic similarity between habitats was $90 \%$ and a principal component analysis showed that species composition varied in a similar manner at edges and interiors. These results indicate that the vegetation of the sampled fragment is not ecologically affected by the creation of edges and suggests that changes in physical conditions and resource availability after edge creation are not enough to eliminate established plants or to alter recruitment and survival of new individuals.
\end{abstract}

Key words: shrubs, edge effect, habitat fragmentation, seasonal scrub vegetation

\section{Introduction}

The ecological importance of edge influence has been extensively documented in fragmented landscapes in temperate and tropical regions (Murcia 1995; Laurance et al. 2002; Ries et al. 2004; Harper et al. 2005). Edge influence, also known as edge effects, is the effect of abiotic and biotic processes at the edge that results in a detectable difference in composition, structure, or function near the edge, as compared with the ecosystem on either side of the edge (Harper et al. 2005). It varies in space and time and directly or indirectly affects microclimate (Camargo \& Kapos 1995), spatial distribution of individuals (Fox et al. 1997; Santos et al. 2008), species composition (Oosterhoorn \& Kappelle 2000; Santos et al. 2008), species interactions (Melo et al. 2006), trophic structure of communities and movement of individuals through landscapes (Laurance et al. 2002). Despite of its importance and ubiquity on landscape dynamics and habitat quality of forest

\footnotetext{
1 Universidade Federal de Pernambuco, Núcleo de Biologia, Centro Acadêmico Vitória, Rua Alto do Reservatório s.n., 55608-680 Vitória de Santo Antão, PE, Brasil

2 Universidad Nacional Autónoma de México (UNAM), Centro de Investigaciones en Ecosistemas, Antigua Carretera a Pátzcuaro 8701, Col. Ex-Hacienda de San José de la Huerta, 58190 Morelia, Michoacán, México

3 Corresponding Author: braulioalmeida@yahoo.com.br
} 
ecosystems (Ries et al. 2004), edge influence remains to be described for the seasonal scrub vegetation of the Brazilian Caatinga.

Edge influence on vegetation structure and composition tends to vary from tropical rain to temperate and boreal forests (Harper et al. 2005). It is particularly evident in tropical rain forest edges (e.g. Fox et al. 1997; Oosterhoorn \& Kappelle 2000; Oliveira et al. 2004; Santos et al. 2008), especially at those where contrast between fragment and surrounding matrix is high. In such forests, proximity to the edge may reduce abundance of shade-tolerant species (Benitez-Malvido 1998), increase tree mortality (Laurance et al. 1998; 2000), favor establishment of pioneer tree species (Nascimento et al. 2006), alter seed dispersal of large-seeded and vertebratedispersed species (Melo et al. 2006), reduce seed germination (Bruna 1999), and increase herbivory by leafcutting ants (Urbas et al. 2007).

A crucial factor determining patch contrast and therefore magnitude of edge influence in forest ecosystems are the structural features of the stand (Harper et al. 2005). Canopy structure controls gradients of wind and light into the forest fragments so that taller canopy height and cover lead to higher magnitude of edge influence. It is expected, for example, that edge influence is less pronounced in forest with high canopy openness, such as some boreal forests. Likewise, landscapes naturally characterized by shrub-dominated cover may have more edge-adapted species, reducing likelihood of detecting edge influence (Harper et al. 2005). This may be the case of the seasonal scrub vegetation of the Brazilian Caatinga, which is usually 10-fold shorter in height than forest vegetation and presents high percentage of deciduous, light-adapted species (Andrade-Lima 1989).

The Caatinga region covers about $800,000 \mathrm{~km}^{2}$ of the Brazilian territory and is comprised of several vegetation types from seasonal tropical dry forest to scrub vegetation, playing an important role in the biogeographical context of South America (Sampaio 1995; Pennington et al. 2000; Prado 2003). All vegetation types together are home to about 932 plant species $(41 \%$ endemic), 148 mammalian species ( $6.7 \%$ endemic), 348 bird species (4\% endemic), 185 fish species (57\% endemic), 156 amphibian and reptile species (15\% endemic) (MMA 2002). With $70 \%$ of its area intact and with only 11 inhabitants per $\mathrm{km}^{2}$ the Brazilian Caatinga has been recognized as a wilderness area (Mittermeier et al. 2003). Despite of its importance, Brazilian Caatinga has been consistently overlooked by biologists and conservationists (Leal et al. 2005).

We focused our study only on the seasonal scrub vegetation of the Brazilian Caatinga, also referred in the text as shrubby Caatinga. Based on their biotic and physical conditions, our prediction a priori was that it is free from edge influence in terms of vegetation structure and composition. We tested the hypotheses that between edge and interior of a shrubby Caatinga fragment there are no differences in: (1) plant height, (2) stem diameter at ground level, (3) stem density, (4) species richness, and (5) species diversity. We calculated magnitude of edge influence for each of these variables and also evaluated floristic similarity between both habitats with a principal component analysis. To our knowledge, this is a pioneer study evaluating edge influence on vegetation parameters of the Brazilian Caatinga.

\section{Material and methods}

Study area - The Brazilian Caatinga is dominated by a xerophytic vegetation type characterized by spiny deciduous shrubs and trees in association with succulent plants, cacti and bromeliads (Prado 2003). In agreement with Andrade-Lima (1981), it includes twelve caatinga types distributed in seven physiognomies - tall caatinga forest, medium caatinga forest, low caatinga forest, open arboreous caatinga, shrubby caatinga, open shrubby caatinga and fringe caatinga forest - and six caatinga physical units. Shrubby caatinga and open shrubby caatinga together compose a single physical unit (unit IV sensu Andrade-Lima 1981) that is mainly formed by Precambrian crystalline rocks. This unit occupies the largest area today and can be commonly found throughout the Caatinga region, including our study area.

This study was conducted out in a partially isolated 690 ha Caatinga fragment located at $550 \mathrm{~m}$ elevation on the Borborema plateau, municipal districts of Boa Vista and Cabaceiras ( $\left.7^{\circ} 20^{\prime} \mathrm{S}-36^{\circ} 18^{\prime} \mathrm{W}\right)$, Paraíba state, Northeast Brazil. The main soil type of the study site is non calcic brown, derived from granites, gneiss and schists (Andrade-Lima 1981). The annual rainfall is $418 \pm 165 \mathrm{~mm}$ (mean $\pm \mathrm{SD} ; 47 \mathrm{yr}$ ), having a record as low as $246 \mathrm{~mm} \mathrm{y}^{-1}$ (Tabarelli et al. 2003). High temperature (average $27^{\circ} \mathrm{C}$ ) and short and irregular rainy seasons complete the semi-arid climate.

The physiognomy at the study site is a scrub vegetation dominated by woody shrubs belonging to the genera Aspidosperma, Mimosa, Jatropha and Caesalpinia (Caatinga types 7, 8, 9, 10 sensu AndradeLima 1981). Vegetation is 2 to $3 \mathrm{~m}$ in height, with some isolated trees of Schinopsis brasiliensis, Myracrodrum urundeuva, Anadenanthera macrocarpa and Tabebuia caraiba reaching up to $20 \mathrm{~m}$ (Andrade-Lima 1989). Emergent, $12 \mathrm{~m}$ tall woody cacti of Pilosocereus piauhiensis are more frequent than trees, but their density is far from being similar to that of shrubs. The non- 
woody shrub cactus Opuntia palmadora is the most abundant species in the study area. All species, except trees and emergent cacti, usually ramify few centimeters above the ground.

The surrounding matrix of the studied edges is Opuntia ficus-indica plantations (locally named palma), which is similar in height and architecture to the very abundant $O$. palmadora. This structural similarity could substantially reduce patch contrast and edge influence (Ewers \& Didham 2005; Harper et al. 2005; Kupfer et al. 2006; Nascimento et al. 2006). However, palma plantations present a higher canopy openness compared to the shrubby Caatinga and are completely harvested in the dry season. As palma should be planted only at the beginning of the next unpredictable rainy season, matrix dynamics include long periods of bare land and therefore constitutes a dissimilar matrix able to create edge influence. According to local people and landowners, palma plantations were established more than 60 years ago. We assumed edges as same age. People also confirm that there are no records of hunting, selective logging or other human disturbances since edge creation.

Data collection - Ten pairs of $10 \times 20 \mathrm{~m}$ plots were randomly placed on the edge $(0 \mathrm{~m})$ and interior areas (100 $\mathrm{m}$ from the nearest edge), with the longer side of each plot situated perpendicular to the border. Pairs were 100-4500 m distant to each other. We used this sampling protocol based on Oliveira et al. (2004) and Santos et al. (2008), who evaluated edge influence on tree species assemblages in the Brazilian Atlantic forest using $10 \times 100 \mathrm{~m}$ plots perpendicular to the border. We reduced plots to $20 \mathrm{~m}$ in length because shrub density in the shrubby Caatinga is much higher than tree density in Brazilian rain forests (B.A. Santos, personal observation). Although some studies have shown that edge influence can be detected up to $300 \mathrm{~m}$ from the edge, we considered $100 \mathrm{~m}$ distant enough to establish control plots because the major changes in vegetation occur in the first $50 \mathrm{~m}$ (Laurance et al. 1998; Ries et al. 2004). In addition, distance of edge influence has been estimated as two or three canopy heights into the forest (Harris 1984).

In each plot, we counted and identified all plants taller than one meter, with stem diameter at ground level (DGL) greater than or equal to three centimeters. Plants recorded in the first five pairs of plots were also measured in height and DGL. We opted to sample plants taller than one meter with DGL $\geq 3 \mathrm{~cm}$ because we were mainly interested in measuring edge influence on adult individuals of shrub species, which represents the majority of the vegetation. Because we did not record seedlings or saplings, this protocol does not allow generalizations about the ecological importance of edge influence on vegetation dynamics as a whole, and should be taken into account on the outcome of our results.

Data analysis - We applied Mann-Whitney tests to compare plant height, stem diameter at ground level (DGL) and species richness between edge and interior (Sokal \& Rohlf 1995). Differences in abundance of plants between edge and interior plots were tested using Student's t-test. Shannon-Wienner indices of diversity were compared using Hutcheson's t-test (Zar 1996). We used Lilliefors test to examine the normality of the data (Zar 1996). All statistical analyses were performed with the software Systat 8.0 (Wilkinson 1998), except Hutcheson's t-test.

Since we were concerned with lack of difference between habitats instead of difference between them, the type II error $(\beta)$ was taken into account rather than the type I error ( $\beta$ ) (Zar 1996). We performed power analyses (evaluated the probability) with the program Power and Precision 2.00 (Borenstein et al. 2001) for parametrics analysis and with the program SimStat for Windows v2.5 (Peladeau 2004) for nonparametric analysis (we used 10,000 bootstrap resampling).

We calculated the Shannon-Wienner index of diversity ( $\mathrm{H}^{\prime}$ ) using log base 2 for edge and interior, and computed Jaccard and Bray-Curtis indices with NTSYSpc 2.01t (Rohlf 2000) to evaluate species similarity between the habitats. An ordination method was used to describe major gradients in vegetation composition among plots. We performed a principal component analysis (PCA) with the PC-ORD 4.0 (McCune \& Mefford 1999) with log-transformed data on species abundances in each plot. Finally, we calculated, according to the model recommended by Harper et al. (2005), the magnitude of edge influence for each of the five variables measured as follow: magnitude of edge influence is equal to $(e-i) /(e+i)$, where $e=$ value of the measured parameter at the edge and $i=$ value of the parameter in the interior. Magnitude varies from -1 to +1 and there is no edge influence when it is equal to 0 .

\section{Results}

As is expected for shrubby Caatinga vegetation, we found a low number of species (Sampaio 1995; Prado 2003). We recorded 2,359 individuals belonging to 22 plant species, of which 21 occurred in edge and 18 in interior plots (Tab. 1). Of the 2,359 individuals recorded, 2,337 $(99.1 \%)$ were shrubs, $14(0.6 \%)$ were woody cacti (Pilosocereus piauhiensis) and $8(0.3 \%)$ were trees (Sideroxylon obtusifolium, Pseudobombax simplicifolium and Commiphora leptopheolus). Five species, accounting for only eight individuals, were restricted to a single habitat 
Table 1. Species sampled in twenty $200 \mathrm{~m}^{2}$ plots in edges and interiors of a 690 ha partially isolated Caatinga fragment, Cabaceiras, Paraíba State, Northeast Brazil (S 7²0' W 36 ${ }^{\circ} 18^{\prime}$ ). ${ }^{1}$ UFP Herbarium, Universidade Federal de Pernambuco, Brazil.

\begin{tabular}{|c|c|c|c|c|c|}
\hline \multirow[t]{2}{*}{ Species } & \multirow[t]{2}{*}{ Voucher ${ }^{1}$} & \multirow[t]{2}{*}{ Vernacularname } & \multirow[t]{2}{*}{ Life-form } & \multicolumn{2}{|c|}{ Abundance } \\
\hline & & & & Edge & Interior \\
\hline \multicolumn{6}{|l|}{ APOCYNACEAE } \\
\hline Aspidosperma pyrifolium Mart. & 37644 & Pereiro & Shrub & 118 & 154 \\
\hline \multicolumn{6}{|l|}{ BORAGINACEAE } \\
\hline Cordia cf. insignis Briq. ex Prance & 38353 & joão-mole & Shrub & 1 & 0 \\
\hline \multicolumn{6}{|l|}{ BURSERACEAE } \\
\hline Commiphora leptopholeus (Mart.) J.B. Gillett & 37847 & imburana & Tree & 2 & 0 \\
\hline \multicolumn{6}{|l|}{ CACTACEAE } \\
\hline Opuntia palmadora $\mathrm{Br}$. et Rose & - & palmatória & Cacti & 372 & 362 \\
\hline Pilosocereus gounellei (Weber) Byl. \& Rowl. & - & xique-xique & Cacti & 38 & 53 \\
\hline P. piauhiensis (Guerke) Byl. \& Rowl. & - & Facheiro & Cacti & 4 & 10 \\
\hline \multicolumn{6}{|l|}{ CAPPARACEAE } \\
\hline Capparis flexuosa $\mathrm{L}$. & 37886 & feijão-bravo & Shrub & 1 & 1 \\
\hline \multicolumn{6}{|l|}{ CELASTRACEAE } \\
\hline Maytenus rigida Mart & 37845 & bom-nome & Shrub & 1 & 0 \\
\hline \multicolumn{6}{|l|}{ EUPHORBIACEAE } \\
\hline Croton cf. argyrophylloides Muell. Arg. & 37641 & marmeleiro & Shrub & 23 & 19 \\
\hline C. campestris St.Hil. & 37889 & Velame & Shrub & 7 & 9 \\
\hline C. sonderianus Muell.Arg. & 37888 & marmeleiro-roxo & Shrub & 292 & 245 \\
\hline Jatropha mutabilis (Pohl.) Baill. & 37890 & pinhão-roxo & Shrub & 76 & 48 \\
\hline J. pohliana Muell.Arg. & - & pinhão-branco & Shrub & 1 & 2 \\
\hline \multicolumn{6}{|l|}{ FABACEAE } \\
\hline Bauhinia cheilantha (Bong.) Steud. & 37642 & Mororó & Shrub & 2 & 2 \\
\hline Caesalpinia pyramidalis Tul. & 37643 & catingueira & Shrub & 74 & 107 \\
\hline Mimosa hostilis Benth. & 37850 & jurema-vermelha & Shrub & 160 & 125 \\
\hline Piptadenia stipulaceae Ducke & 37645 & jurema-branca & Shrub & 16 & 15 \\
\hline \multicolumn{6}{|l|}{ MALVACEAE } \\
\hline Pseudobombax simplicifolium A.Robyns & 37646 & Imbiratã & Tree & 0 & 2 \\
\hline Sida $\mathrm{sp}$ & 37846 & Malva & Shrub & 2 & 0 \\
\hline \multicolumn{6}{|l|}{ PHYLLANTACEAE } \\
\hline Phyllanthus sp. & 37887 & pau-leite & Shrub & 1 & 3 \\
\hline \multicolumn{6}{|l|}{ SAPOTACEAE } \\
\hline $\begin{array}{l}\text { Sideroxylon obtusifolium (Humb. ex Roem. \& } \\
\text { Schult.) T.D. Penn. }\end{array}$ & 37849 & quixabeira & Tree & 2 & 2 \\
\hline Indeterminate & - & Marmelada & Shurb & 6 & 1 \\
\hline
\end{tabular}

(Tab. 1), four species in the edge (Cordia $\mathrm{cf}$. insignis, Maytenus rigida, Commiphora leptopheolus, Sida sp.) and one in the interior (Pseudobombax simplicifolium).

All three structural parameters analyzed (plant height, stem diameter at ground level, and number of individuals) resulted in no significant differences between edge and interior. Plant height in edge plots ranged from 1 to $9 \mathrm{~m}$ (median $1.9 \mathrm{~m}$ ) and in interior plots from 1 to $8 \mathrm{~m}$ (median $1.8 \mathrm{~m} ; \mathrm{U}=132,275 ; P=0.735, N=1,023$; $1-\beta=0.713$; Fig. 1A). Likewise, diameter at ground level in edge plots ranged from 3 to $51.8 \mathrm{~cm}$ (median $5.7 \mathrm{~cm}$ ) and in interior plots from 3 to $29.3 \mathrm{~cm}$ (median $5.6 \mathrm{~cm})(\mathrm{U}=128,863 ; P=0.700 ; N=1,023$; $1-\beta=0.728$; Fig. 1B). The average number of individuals at edges was $119.9 \pm 29.11$ individuals $/ 200 \mathrm{~m}^{2}$ (mean $\pm \mathrm{SD}$ ), while in the interior it was $116 \pm 22.11$ individuals $/ 200 \mathrm{~m}^{2}(\mathrm{t}=0.337$, $\mathrm{df}=18, P=0.740$; $1-\beta=0.72$; Fig. 1C). Species richness was also statistically equal between edge and interior habitats ( $\mathrm{U}=50.5, P=0.969, N=20 ; 1-\beta=0.71)$, with both ranging from 8 to 13 species $/ 200 \mathrm{~m}^{2}$ (Fig. 1D). The same was found for species diversity, with edge presenting 2.80 and interior 2.84 bits per individual ( $\mathrm{t}=-0.626 . v=2,357.6, P=0.53)$.

Vegetation composition of edge and interior presented high floristic similarity - the qualitative Jaccard index was 0.77 and the quantitative Bray-Curtis distance was 0.10 (0.90 similarity). The PCA ordination diagram showed that both edge and interior habitats did not form distinct floristic groups (Fig. 2). Ordination was best fit by a three-axis solution because broken-stick eigenvalues for axes 1, 2, and 3 were lower than the actual eigenvalues (axis $1=4.4 v s .7 .7$, axis $2=3.2 v s .6 .0$ and axis $3=2.6$ vs. 3.5, respectively). The first three axes accounted 
for $65.1 \%$ of the variability in the data (axis $1=29.2 \%$, axis $2=22.7 \%$ and axis $3=13.2 \%$ ). When ordination scores were compared for edge versus interior plots, there were no significant differences in ordination scores on the three axes (MANOVA, $F_{3,16}=0,246 ; P=0,863$ ), indicating that vegetation composition at edges and interiors varied in a similar manner. In addition, magnitude of edge influence varied from $-0,027$ to 0,027 (Tab. 2), suggesting no edge influence for the measured variables.

\section{Discussion}

Our results suggest that vegetation structure and composition are unlikely to be changed by the creation of edges in the shrubby Caatinga. It was statistically supported by the power analysis of the tested hypotheses, which were all larger than $70 \%$, indicating low probability of wrongly accepting edge as being equal to interior plots. Although we have sampled only one fragment and have collected no data on other vegetation parameters, such as growth, reproduction, and population dynamics, our results permit some inferences about what kind of mechanisms appear to be responsible for the absence of edge influence in the studied vegetation.

Forest ecosystems usually experience three types of edge influence. Murcia (1995) classified them into (1) abiotic effects, which involve changes in the environmental conditions that result from the proximity
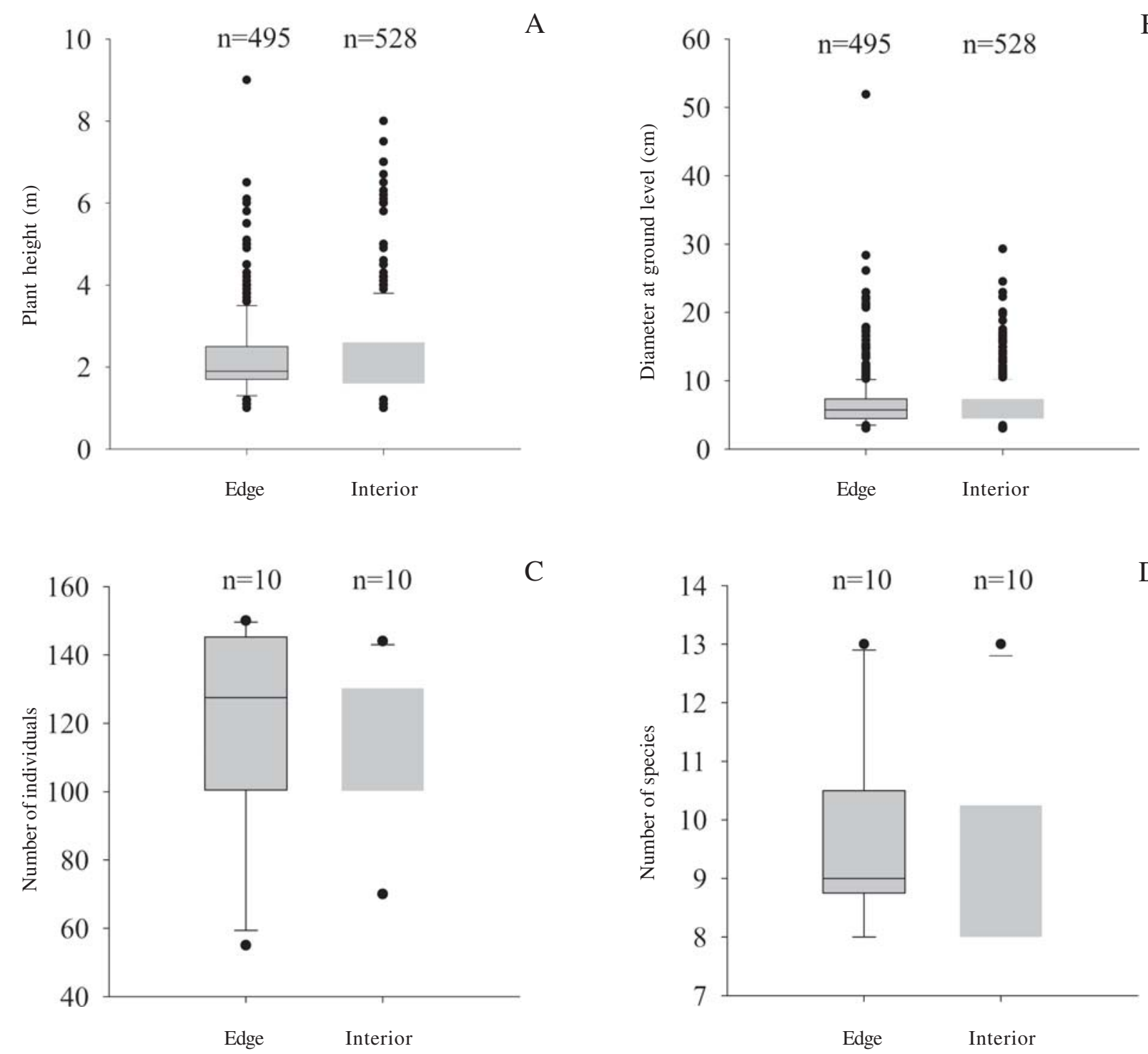

Figure 1. Plant height (A), diameter at ground level (B), number of plant individuals (C), and number of plant species (D) in edge and interior habitats at Cabaceiras, Paraíba State, Northeast Brazil. The median (thin line), 25 th and 75 th percentiles (boundaries of boxes), 5 th and 95 th percentiles (whiskers above and below box plots), and all outliers (black circles) are indicated for each habitat. 


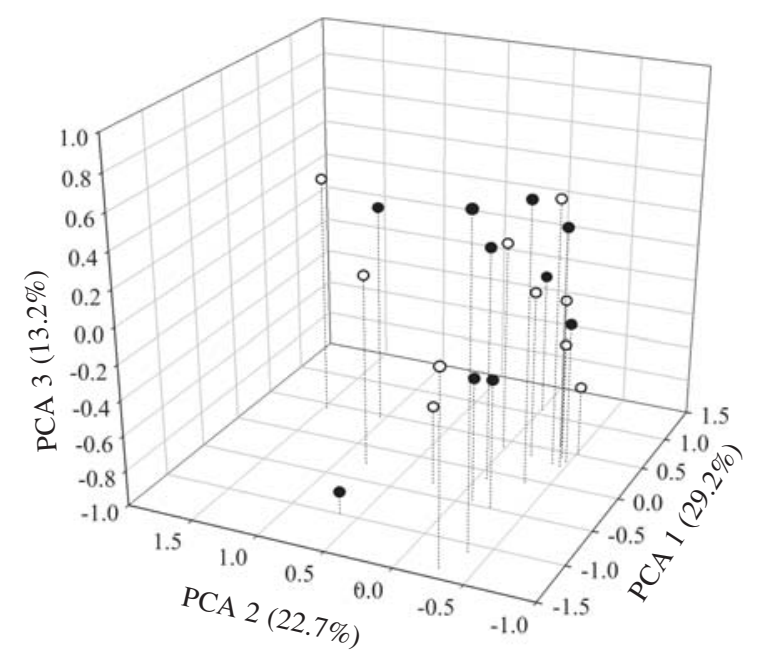

Figure 2. Ordination of twenty $200 \mathrm{~m}^{2}$ plots based on 22 plant species in the seasonal scrub vegetation of the Caatinga, Northeast Brazil. The amount of variation explained by each axis is showed in parentheses in the axis legend $(\bullet=$ Edige; $\mathrm{O}=$ Interior $)$.

to a structurally dissimilar matrix (e.g. increase in wind turbulence and decrease in air and soil moisture); (2) direct biological effects, involving changes in the abundance and distribution of species caused directly by the physical conditions near the edge and determined by the physiological tolerances of species to the new physical conditions (e.g. tree mortality due to wind turbulence or habitat desiccation); and (3) indirect biological effects, which involve changes in species interaction, such as predation, parasitism, competition, herbivory, and biotic pollination and dispersal. All effects vary differently in space and time and tend to form a chronological gradient after edge creation from shortterm abiotic effects to long-term direct and indirect biological effects. Nonetheless a given edge may simultaneously experience all types of edge influence, enhancing forest alterations (Murcia 1995). Along the time, taxonomical and functional differences between

Table 2. Magnitude of edge influence for five vegetation parameters in twenty $200 \mathrm{~m}^{2}$ plots in edges and interiors of a 690 ha partially isolated Caatinga fragment, Cabaceiras, Paraíba State, Northeast Brazil (7²0' S $\left.36^{\circ} 18^{\prime} \mathrm{W}\right)$. Values were calculated according to Harper et al. (2005) and vary from -1 to +1 ; there is no edge influence when equal to 0 .

\begin{tabular}{lrrr}
\hline & Edge & Interior & Magnitude \\
\hline Plant height $(\mathrm{m})$ & 1.9 & 1.8 & 0.0270 \\
Stem density/200 $\mathrm{m}^{2}$ & 119.9 & 116 & 0.0165 \\
Diameter at ground level $(\mathrm{cm})$ & 5.7 & 5.6 & 0.0088 \\
Species richness & 9 & 9.5 & -0.0270 \\
Species diversity & 2.80 & 2.84 & -0.0071 \\
\hline
\end{tabular}

plant assemblages of edge and interior tend to be amplified, increasing the probability of detecting edge effects.

In this study we evaluated only direct biological edge effects and did not find differences on vegetation structure and composition. Since this type of edge influence is a cascade effect of changes in the physical conditions and resource availability (Murcia 1995), abiotic edge effects such as those described for forest ecosystems appear to be lacking in the shrubby Caatinga. Most of this disagreement may be explained by the type of resources changed after edge creation. In forest ecosystems, light is a limiting resource and creation of edges leads to habitat desiccation close to the edge (Camargo \& Kapos 1995). In the shrubby Caatinga, however, light is an abundant resource and habitat is naturally desiccated (Andrade-Lima 1989). The main limiting resource in the shrubby Caatinga is water, which depends primarily on uncertain rainfalls and compact and shallow soils for storage (Sampaio 1995; Tabarelli et al. 2003). We hypothesize that creation of edges does not alter water availability for shrubs, cacti and trees in this type of vegetation. Because of this plants do not respond to the proximity of the edge, which means no change in species abundance and distribution. If plants respond to abiotic changes in the edges of the shrubby Caatinga, it should be detected in terms of water availability rather than light and should be unpredictable in time because of the irregularity of rainy seasons, being insignificant for shrubs, cacti and trees in an ecological time.

Absence of edge influence is not a new finding in the literature. In fact, recent reviews on edge research have shown that no edge responses are very frequent (Murcia 1995; Ries et al. 2004; Harper et al. 2005). Ries et al. (2004), for example, reviewed 900 papers on terrestrial edge responses and found that a large number of studies found neutral response to edge creation. Ries et al. (2004) then created five predictive models of edge influence based on the amount of available resource in the matrix-edge-fragment gradient. According to the authors, when two adjacent habitats differ from each other in terms of resource availability (e.g. pasture matrix and forest), negative and positive responses are predicted. On the other hand, when two adjacent habitats contain relatively equal amounts of resources, no response is predicted because proximity to the edge confers no additional access to different resources. This is probably the case of the Caatinga-palma gradient, where both sides of the edge appear to present equal amounts of the same resources.

Plant responses to edge creation can be very fast in forest ecosystems (Laurance et al. 2002). Mortality of 
non-pioneer tropical species due to physiological intolerance near the edge, for instance, is a welldocumented consequence of edge creation in tropical rain forests (Laurance et al. 1998; 2000). Over time, large, long-lived and shade-tolerant trees tend to be replaced by small, short-lived and shade-intolerant trees (Oliveira et al. 2004; Nascimento et al. 2006; Santos et al. 2008), altering seed rain (Melo et al. 2006), germination (Bruna 1999) and seedling recruitment in forest edges (Benitez-Malvido \& Martínez-Ramos 2003). A few decades after fragmentation, loss of non-pioneer species and disruption of ecological processes degenerate rain forest edges, leading to drastic changes in tree assemblage composition (Santos et al. 2008). In the seasonal scrub vegetation of the Caatinga, however, no plant response to edge creation is predicted because no physiological intolerance is expected. Consequently, mortality of adults established before edge creation and recruitment and survival after edge creation appear to be unaffected by the proximity to the edge. These inferences are supported by the near-zero values of magnitude of edge influence even 60 years after edge creation, a time enough to drastically alter plant assemblages in Amazonian and Atlantic forest edges (Laurance et al. 2002; Santos et al. 2008).

Although this study has been carried out in a single fragment and with a categorized experimental design (edge vs. interior rather than multiple distances to the edge), we have shown that plant species of the shrubby Caatinga tend to distribute equally across edges and interiors, a fact that should be taken into account by ecologists and conservationists concerned with this ecosystem. Because edges are suitable for all plant species, the shape of fragments may not affect the edge/core ratio or the total area of suitable habitats (Kupfer et al. 2006). Hence, even narrow ecological corridors could improve the connectivity among shrubby Caatinga fragments if it is required for the maintenance of populations in the long run. Nevertheless, it is far from suggesting that edges can be arbitrarily created in the Caatinga. Edge influence is just one of a myriad of effects faced by fragmented habitats (Ewers \& Didham 2005). Habitat loss per se can lead to species loss (Fahrig 2003). Moreover, edges facilitate access for logging, hunting, and fire, which can lead to species loss as well (Tabarelli et al. 2004).

In summary, the edge-related ecological responses described for forest ecosystems are unlikely to be detected in the shrubby Caatinga, probably because there are no significant changes in the environmental conditions and in the access to different resources after edge creation. Consequently, plants distribute in space irrespective to the proximity to the edge. We hypothesize that light plays an irrelevant role in edge dynamics of this type of vegetation and that water availability may govern unpredictable edge-induced responses. Further studies evaluating long-term changes in water availability and life-history features of plant species, such as growth, survival and reproduction, are needed for a better understanding of the vegetation dynamics at the edges of the shrubby Caatinga.

\section{Acknowledgements}

We thank CNPq (Conselho Nacional de Desenvolvimento Científico e Tecnológico - Brazilian Council for Scientific and Technologic Development) and CAPES (Coordenação de Aperfeiçoamento de Pessoal de Nível Superior - Brazilian Coordination for the Improvement of Higher Level Personnel) for funding this study. The text benefited from comments by Julieta Benitez-Malvido, Glauco Machado, Inara Leal, Felipe Melo, Marion Adeney, Erich Fischer and two anonymous reviewers.

\section{References}

Andrade-Lima, D. 1981. The Caatinga dominium. Revista Brasileira de Botânica 4: 149-153.

Andrade-Lima, D. 1989. Plantas das Caatingas. Rio de Janeiro, Academia Brasileira de Ciências.

Benitez-Malvido, J. 1998. Impact of forest fragmentation on seedling abundance in a tropical rain forest. Conservation Biology 12: 380-389.

Benitez-Malvido, J. \& Martínez-Ramos, M. 2003. Influence of edge exposure on tree seedling species recruitment in tropical rain forest fragments. Biotropica 35: 530-541.

Borenstein, M.; Rothstein, H. \& Cohen, J. 2001. Power and precision. Englewood, Biostat Inc.

Bruna, E.M. 1999. Seed germination in rainforest fragments. Nature 402: $1-139$.

Camargo, J.L.C. \& Kapos, V. 1995. Complex edge effects on soil moisture and microclimate in a central Amazonian forest. Journal of Tropical Ecology 11: 205-221.

Ewers, R.M. \& Didham, R.K. 2005. Confouding factors in the detection of species responses to habitat fragmentation. Biological Review: 1-26.

Fahrig, L. 2003. Effects of habitat fragmentation on biodiversity. Annual Review of Ecology, Evolution and Systematic 34: 487-515.

Fox, B.J.; Taylor, J.E.; Fox, M.D. \& Williams, C. 1997. Vegetation changes across edges of rainforest remnants. Biological Conservation 82: $1-13$.

Harper, K.A.; MacDonald, S.E.; Burton, P.J.; Chen, J.; Brosofske, K.D.; Saunders, S.C.; Euskirchen, E.S.; Roberts, D.; Jaiteh, M.S. \& Esseen, P. 2005. Edge influence on forest structure and composition in fragmented landscapes. Conservation Biology 19: $768-782$.

Harris, L.D. 1984. The fragmented forest: island biogeography theory and the preservation of biotic diversity. Chicago, University of Chicago Press.

Kupfer, J.A.; Malanson, G.P. \& Franklin, S.B. 2006. Not seeing the ocean for the islands: the mediating influence of matrix-based processes on forest fragmentation effects. Global Ecology and Biogeography 15: 8-20. 
1084 Santos \& Santos: Are the vegetation structure and composition of the shrubby Caatinga free from edge influence?

Laurance, W.F.; Ferreira, L.V.; Rankin-De Merona, J.M. \& Laurance, S.G. 1998. Rain forest fragmentation and the dynamics of Amazonian tree communities. Ecology 79: 2032-2040.

Laurance, W.F.; Delamonica, P.; Laurance, S.G.; Vasconcelos, H.L. \& Lovejoy, T.E. 2000. Rainforest fragmentation kills big trees. Nature 404: 1-836

Laurance, W.F.; Lovejoy, T.E.; Vasconcelos, H.L.; Bruna, E.M.; Didham, R.K.; Stouffer, P.C.; Gascon, C.; Bierregaard, R.O.; Laurance, S.G. \& Sampaio, E. 2002. Ecosystem Decay of Amazonian Forest Fragments: a 22-Year Investigation. Conservation Biology 16: 605-618.

Leal, I.R.; Silva, J.M.C.; Tabarelli, M. \& Lacher, T.E. 2005. Changing the course of biodiversity conservation in the Caatinga of northeastern Brazil. Conservation Biology 19: 701-706.

McCune, B. \& Mefford, M.J. 1999. PC-ORD, multivariate analysis of ecological data. Version 4.17. Oregon, Glenenden Beach, MjM Software.

Melo, F.P.L.; Dirzo, R. \& Tabarelli, M. 2006. Biased seed rain in forest edges: evidence from the Brazilian Atlantic forest. Biological Conservation 132: 50-60.

Mittermeier, R.A.; Goettsch Mittermeier, C.; Gil, P.R.; Pilgrim, J. Fonseca, G.; Brooks, T. \& Konstant, W.R. 2003. Wilderness: Earth's Last Wild Places. Chicago, University of Chicago Press.

MMA. 2002. Avaliação e ações prioritárias para a conservação da biodiversidade da caatinga. Brasília, Universidade Federal de Pernambuco, Fundação de Apoio ao Desenvolvimento, Conservation International do Brasil, Fundação Biodiversitas e EMBRAPA Semi-Árido.

Murcia, C. 1995. Edge effects in fragmented forests: implications for conservation. Trends in Ecology and Evolution 10 58-62.

Nascimento, H.E.M.; Andrade, A.C.S.; Camargo, J.L.C.; Laurance, W.F.; Laurance, S.G. \& Ribeiro, J.E.L. 2006. Effects of the surrounding matrix on tree recruitment in Amazonian forest fragments. Conservation Biology 20: 853-860.

Oliveira, M.A.; Grillo, A.S. \& Tabarelli, M. 2004. Forest edges in the Brazilian Atlantic forest: drastic changes in tree species assemblages. Oryx 38: 389-394.
Oosterhoorn, M. \& Kappelle, M. 2000. Vegetation structure and composition along an interior-edge-exterior gradient in a Costa Rican montane cloud forest. Forest Ecology and Management 126: 291-307.

Peladeau, N. 2004. Simstat. Montreal, Provalis Research.

Pennington, R.T.; Prado, D.E. \& Pendry, C.A. 2000. Neotropical seasonally dry forests and quaternary vegetation changes. Journal of Biogeography 27: 261-273.

Prado, D.E. 2003. As caatingas da América do Sul. Pp. 3-73. In: I.R Leal; M. Tabarelli \& J.M.C. Silva (eds.). Ecologia e conservação da Caatinga. Recife, Editora da Universidade Federal de Pernambuco.

Ries, L.; Fletcher, R.J.; Battin, J. \& Sisk, T.D. 2004. Ecological responses to habitat edges: mechanisms, models, and variability explained. Annual Review of Ecology, Evolution and Systematic 35: 491-522.

Rohlf, F.J. 2000. NTSYSpc: numerical taxonomy and multivariate data analysis system. Ver. 2.01. Setauket, Exeter Software.

Sampaio, E.V.S.B. 1995. Overview of the Brazilian Caatinga. Pp. 35-63. In: S.H. Bullock; H.A. Mooney \& E. Medina (eds.). Seasonal dry tropical forests. London, Cambridge University Press.

Santos, B.A.; Peres, C.A.; Oliveira, M.A.; Grillo, A.; Alves-Costa, C.P. \& Tabarelli, M. 2008. Drastic erosion in functional attributes of tree assemblages in Atlantic forest fragments of northeastern Brazil. Biological Conservation 141: 249-260.

Sokal, R.R. \& Rohlf, F.J. 1995. Biometry. New York, Freeman and Company.

Tabarelli, M.; Vicente, A. \& Barbosa, D.C.A. 2003. Variation of seed dispersal spectrum of woody plants across a rainfall gradient in north-eastern Brazil. Journal of Arid Environments 53: 197-210.

Tabarelli, M.; Silva, J.M.C. \& Gascon, C. 2004. Forest fragmentation, synergisms and the impoverishment of neotropical forests. Biodiversity and Conservation 13: 1419-1425.

Urbas, P.; Araújo, M.V.; Leal, I.R. \& Wirth, R. 2007. Cutting more from cut forests: edge effects on foraging and herbivory of leafcutting ants. Biotropica 39: 489-495.

Wilkinson, L. 1998. SYSTAT. Ver 8.0. Chicago, SPSS

Zar, J.H. 1996. Biostatistical Analysis. Third ed. New Jersey, Prentice-Hall. 